\title{
TECHNICAL AND ECONOMIC ASPECTS OF PHOTOVOLTAIC CONVERSION OF SOUTHERN POLAND
}

\author{
ASPEKTY TECHNICZNE I EKONOMICZNE \\ KONWERSJI FOTOWOLTAICZNEJ W WARUNKACH POLSKI POLUDNIOWEJ
}

\begin{abstract}
The article presents the results of a 13-year tests and analysis of performance and energy and electrical charge yield for typical photovoltaic modules made of different absorbers. Modules were installed on the south wall of Opole University building (at kard. B. Kominka Street). Registered in this period (2001-2013) values energy and charge of tested modules are presented in reference to $1 \mathrm{~W}_{\mathrm{p}}$ their nominal power and to $1 \mathrm{~m}^{2}$ of PV modules. Their annual and monthly distributions, with particular emphasis on the seasonal changes of its parameters and phenomena of aging and degradation of the PV modules structure were shown. In the final part of the article was presented an economic analysis of the profitability of investment in $20 \mathrm{~kW}_{\mathrm{p}}$ grid connected PV system with and without implemented the program to support investment in renewable energy, which respect to the newly implemented in Poland Act on RES.
\end{abstract}

Keywords: solar cells, energy gained, energetic efficiency, performance ratio $(P R)$, solar radiation, solar energy, photovoltaics

\section{Introduction}

In recent years all over the world there is increasing interest in alternative, environmental clean sources of electricity. The largest of these sources, and at the same time practically unlimited and widely available, is the energy of solar radiation. The development of solar energy is mainly concentrated around the technologies using photothermal and photovoltaic conversion. Photovoltaic (PV) conversion is the most perfect way to process solar energy into electricity, as it is a direct conversion. This method is highly popularized worldwide. The primary objective of the research at the Opole University is developing of so-called low-cost solar energy conversion technologies. Technology for which coefficient of performance of energy produced in photovoltaic systems based on purchase cost of $1 \mathrm{~W}_{\mathrm{p}}$ of PV modules is the largest in our geographical and climatic conditions. An additional objective is to promote the development of solar

\footnotetext{
${ }^{1}$ Division of Physicochemical Research, Opole University, ul. kard. B. Kominka 6, 45-032 Opole, Poland, phone +48 7740160 42, fax +48 7740160 51, email: maria.waclawek@uni.opole.pl

${ }^{2}$ Institute of Industrial Electrotechnics, Faculty of Electrical Engineering, Czestochowa University of Technology, al. Armii Krajowej 17, 42-200 Częstochowa, Poland, email: zaremba@el.pcz.czest.pl

*Corresponding author: trodziewicz@wp.pl
} 
energy through the use of PV systems measurement data for training activity at the Opole University and to analyse the profitability these systems in the Southern Poland climate.

The main objectives of the very well support the implementation of the provisions of „Directive 2009/28/EC of the European Parliament and of the Council of 23 April 2009 on the promotion of the use of energy from renewable sources and amending and subsequently repealing Directives 2001/77/EC and 2003/30/EC" and strategies for shaping, prospects and directions of development of the national energy policy - Polish Energy Policy until 2030. These objectives can be achieved through changes that will prepare our economy and society to the challenges of a new era in which power to a significant extent is based on distributed generation using, inter alia, renewable energy sources (RES). This approach will enable effective management of the deposits of fossil fuels which are running out. Currently, the foundation of Polish energy security is the use of domestic coal, but in subsequent decades, the share of gas in the energy balance will be gradually reduced in favour of other sources, mainly the photovoltaic conversion.

\section{Description of research station}

In September 1998 the research station to monitor of PV modules performance and the two PV modules were installed on the roof of the Opole University building [1]. 4 new modules were installed soon (Fig. 1).

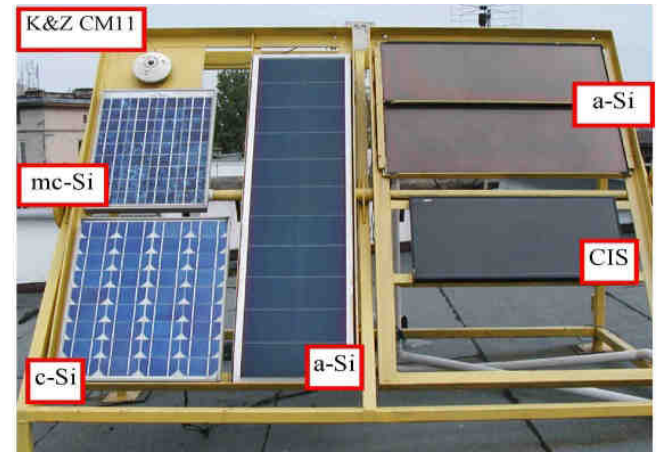

Fig. 1. Research station to test PV modules in the outdoor conditions. View from 2002

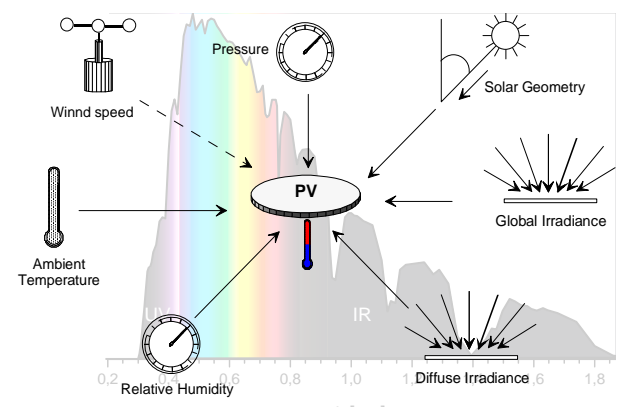

Fig. 2. Atmospheric parameters (also insolation spectrum) measured by meteorological station and PV modules temperature 

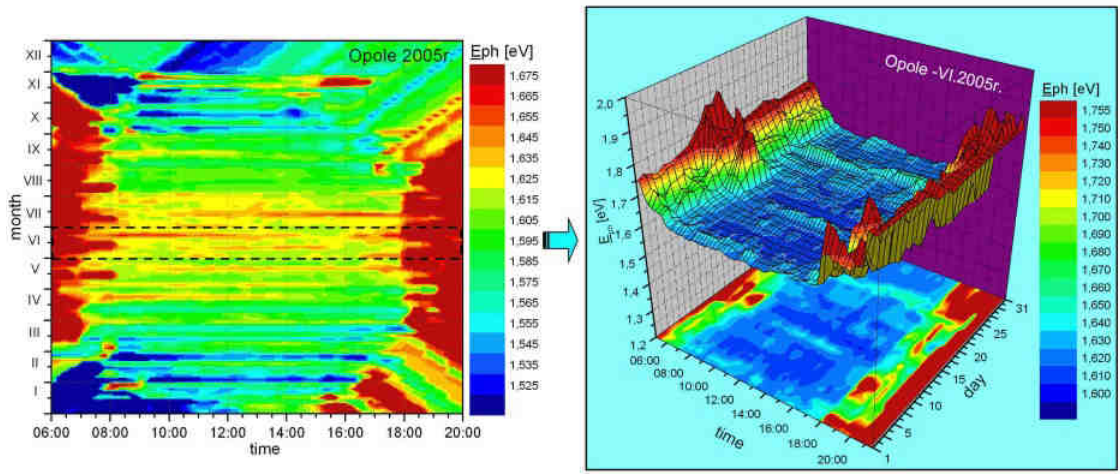

Fig. 3. Photon energy distribution in Opole

The research station consists of six autonomous units to measure I-U curves of tested modules [2-4] and two units for insolation incident on the module surface (one for pyranometer CM11 (Kipp\&Zonen), the second for the calibrated photocell) [5-8]. Additionally, this station measures ambient and module temperatures. It enables to test of different PV modules with short-circuit current as high as $5 \mathrm{~A}$ and open circuit voltage to $25 \mathrm{~V}$. I-U characteristics of each module are measured within intervals of 15 to 120 seconds. Short-circuit currents are measured continuously and are integrated in time, in purpose to calculate electric charge gathered by tested PV modules. PV station works together with local meteorological station (Fig. 2), which enables to study of impact of local climatic conditions on PV parameters. The main factor, which influences on produced charge and other parameters of tested modules is distribution of solar radiation spectrum on module surface (Fig. 3).

\section{Results}

\section{Analysis of energetic efficiency}

In Figure 4 the long-term results of daily energy efficiency of different PV modules are shown. For the analysis data from the years 2001-2013 gathered at the Opole University are used In graphs can be observed aging process modules made from amorphous silicon. Daily (1), monthly (2) and annual (3) values of the energy efficiency for the different tested modules are calculated from the following relations [1,9-12]:

$$
\begin{aligned}
\eta_{E \mid \text { day }}= & \frac{\int_{0}^{d a y} P(t) d t}{\int_{0}^{\text {day }} G_{0}(t) d t} \\
\eta_{E \mid \text { month }}= & \frac{\int_{0}^{\text {month }} P(t) d t}{\int_{0}^{\text {month }} G_{0}(t) d t}
\end{aligned}
$$




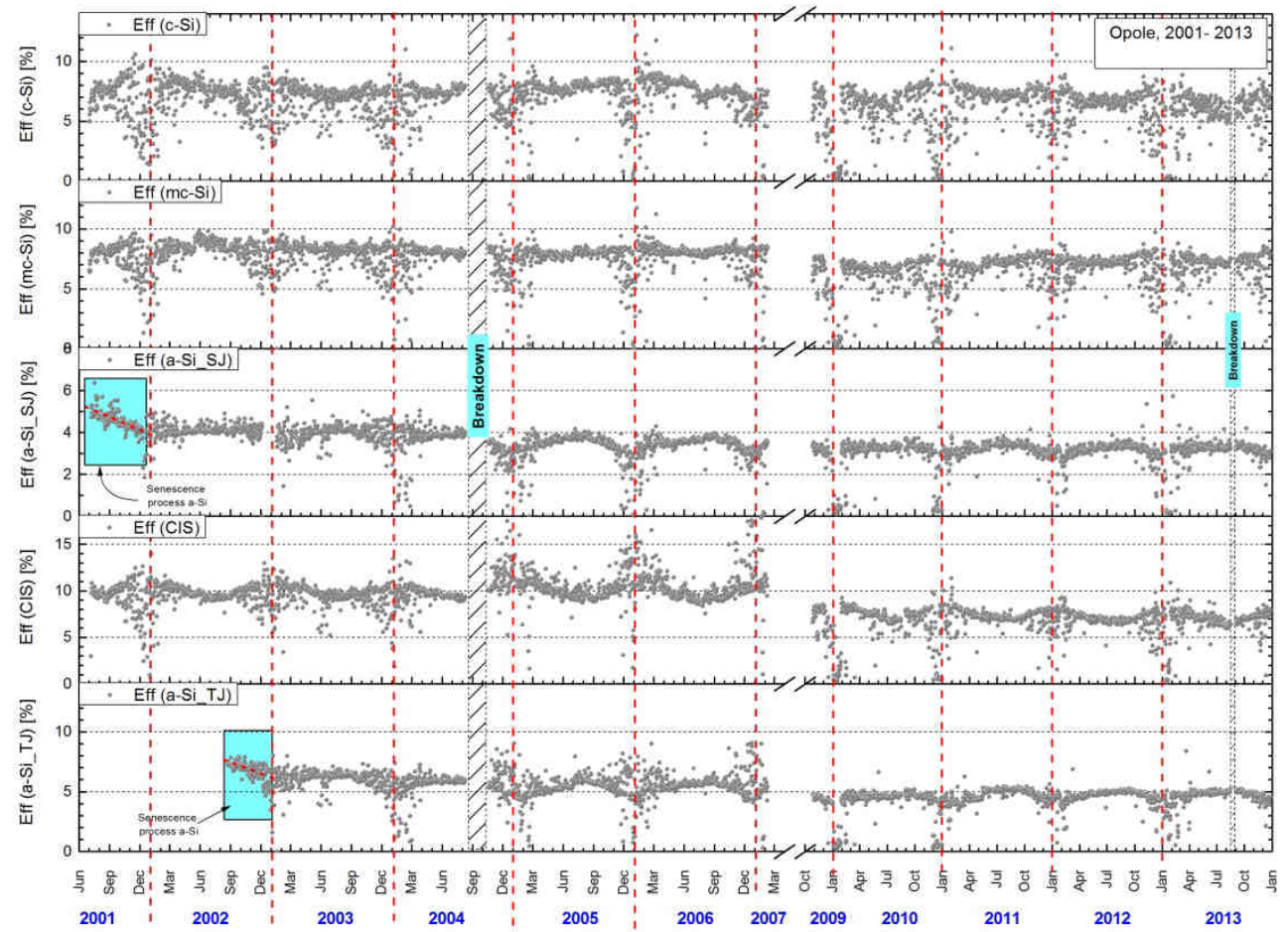

Fig. 4. Efficiencies of modules made of different materials (c-Si - monocrystalline silicon; mc-Si - microcrystalline silicon; a-Si SJ - single junction amorphous silicon; a-Si TJ - triple junction amorphous silicon) $[1,12]$

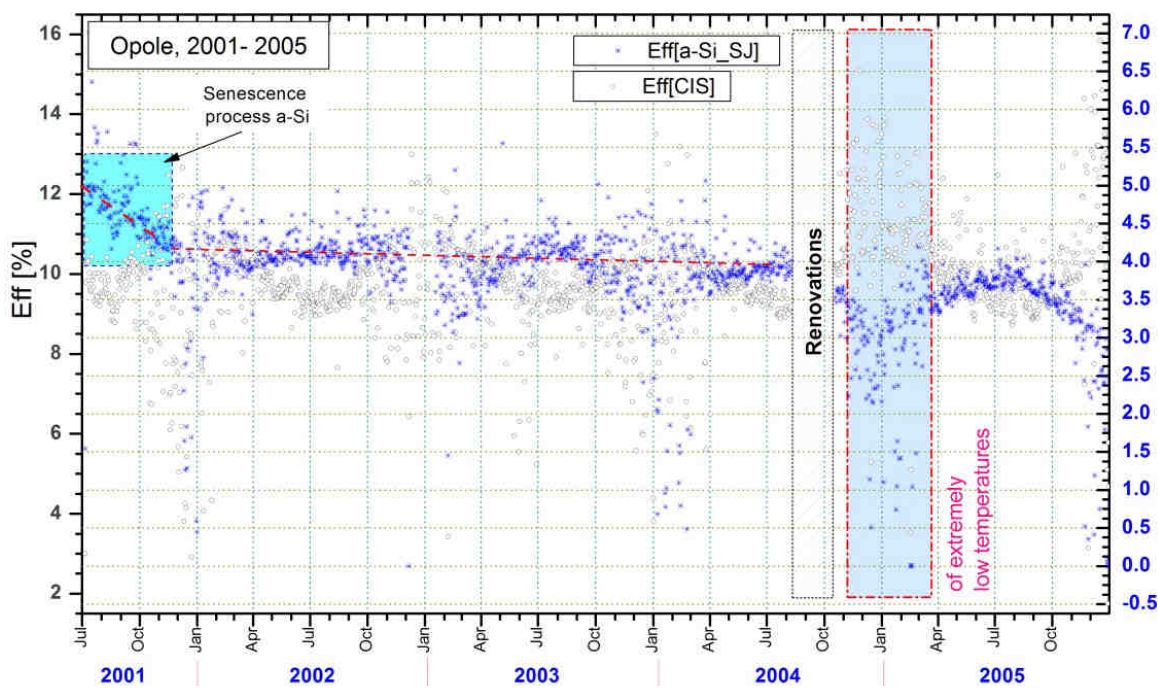

Fig. 5. Changes in seasonal energy efficiency of CIS and amorphous silicon modules within five years [1] 


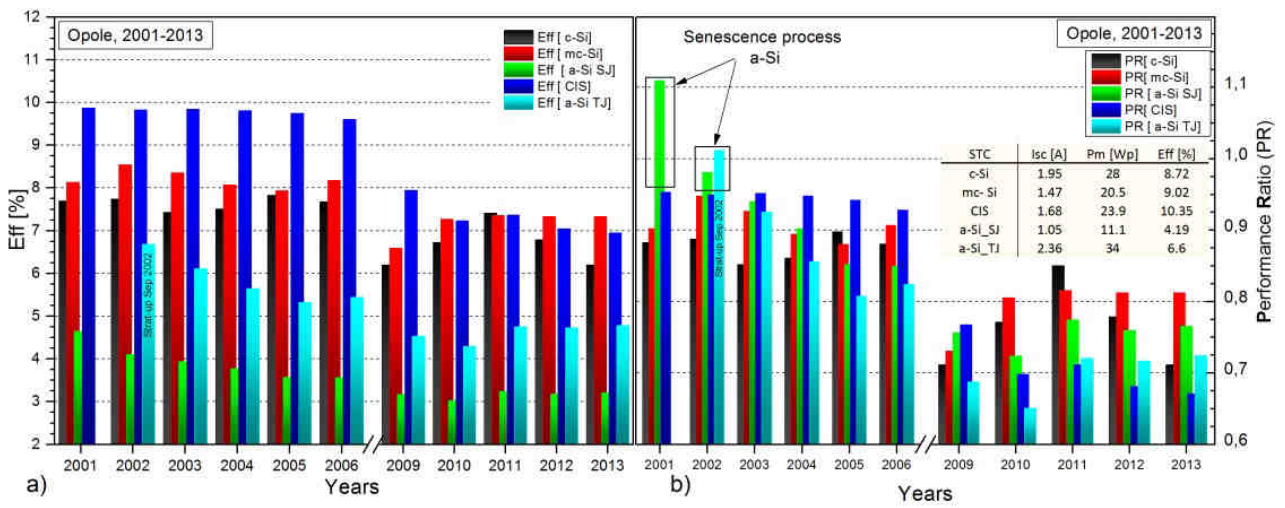

Fig. 6. Yearly: a) values efficiencies, and b) values of PR for different modules

$$
\eta_{\text {Eyear }}=\frac{\int_{0}^{\text {year }} P(t) d t}{\int_{0}^{\text {year }} G_{0}(t) d t}
$$

In Figure 5 the seasonal changes in daily energy efficiency for the CIS and amorphous silicon modules during five years of observation are shown. It very clearly reveals the cyclical nature of changes. Particularly noteworthy is the observation that the weather conditions favourable for amorphous silicon modules are also the least favourable for CIS modules.

\section{Analysis of $P R$ factor}

$P R$ factor (Performance Ratio) is a measure of the module ability to work in the environment, that determines the degree of deterioration of the energy accumulation in photovoltaic module, occurring at work in the real climate conditions in relation to its work at standard test conditions (STC). The value of this ratio is not constant. As the efficiency, PR coefficient depends on the absorber, the technology and the specific climatic conditions in the place of work.

In Figure 6 were compared the annual average $P R$ values for different PV modules. The analysis of this Figure shows that the most appropriate for use in Polish climatic conditions are modules with mc-Si and CIS absorbers, which in the first six years of continuous observation has $P R$ ratio at 0.95 .

In Figure 7 are shown the daily PR values for modules tested in the years 2001-2013. For the calculations were taken real energy efficiencies of modules and their efficiency calculated under STC conditions [1, 9-12]:

$$
\left.P R\right|_{\text {day, } \text { month,year }}=\frac{\left.\eta\right|_{\text {day,month,year }}}{\eta_{S T C}}
$$




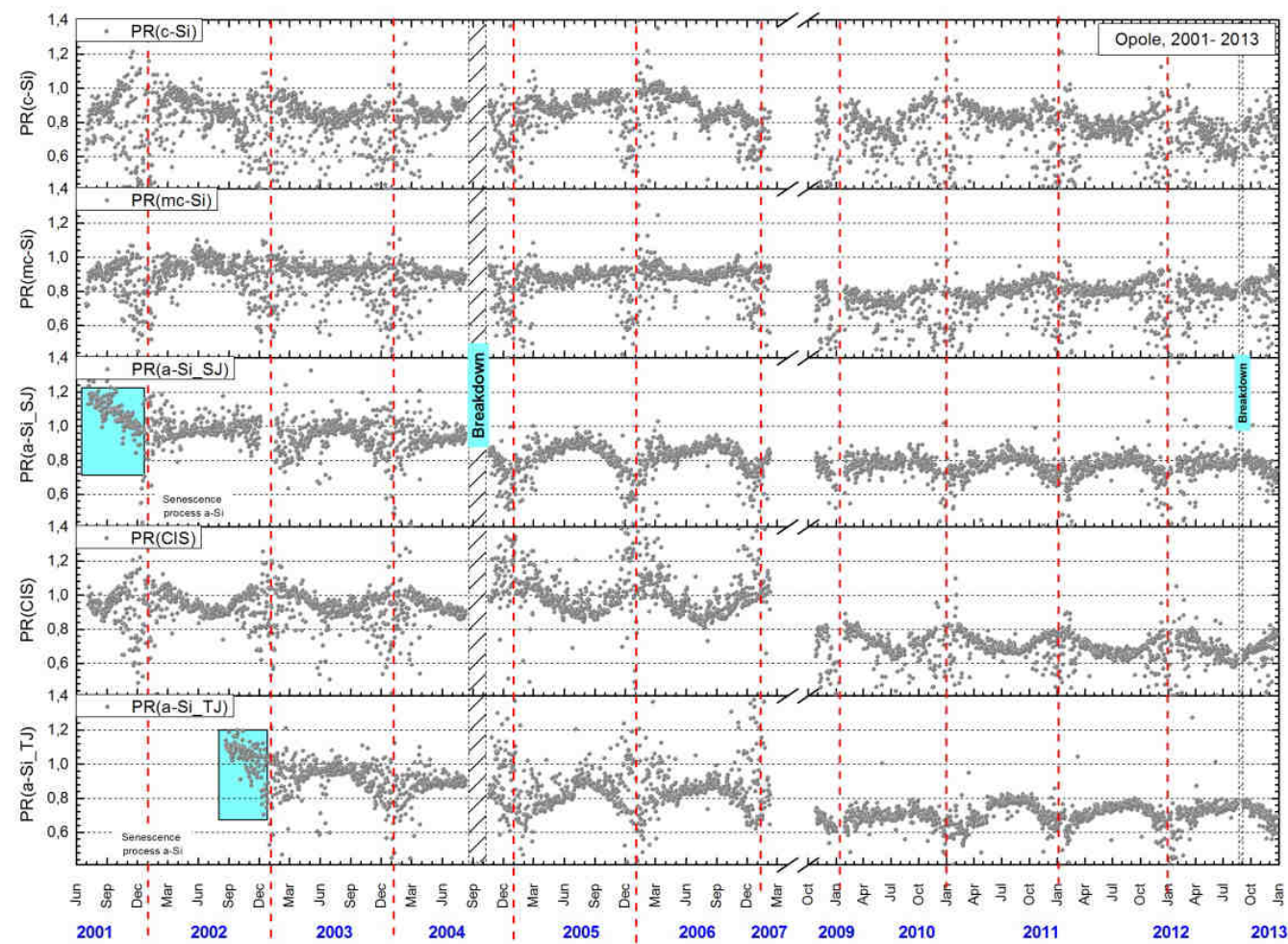

Fig. 7. Daily $P R$ values for different PV modules in the years 2001-2013 [1, 12]

\section{Analysis of charge and energy}

For comparison the ability of the charge accumulation and energy generation PV modules (having different technical parameters) the results were shown:

- $\quad$ per $1 \mathrm{~W}$ of power $P_{m}$ obtained under STC for analysis of the energy yield $\left(E_{\max }\right)$;

- per 1 A of $I_{S C}$ current obtained in STC conditions for analysis of the global yield of generated charge,

First measured parameters of the tested modules - in the case of amorphous modules after year of operation ${ }^{3}$. The measured value of the maximum current $\left(I_{S C}\right)$ and maximum power $\left(P_{m}\right)$ converted to values obtained under STC using a Blaesser procedure [6-9].

\footnotetext{
${ }^{3}$ In the first half of year, there was a $20 \%$ drop in performance and power of amorphous modules. This decline was expected by the manufacturer. It caused the need to determine the actual parameters of the modules after a period of aging. Therefore, to further study the module parameters were taken after one year of operation
} 
a)

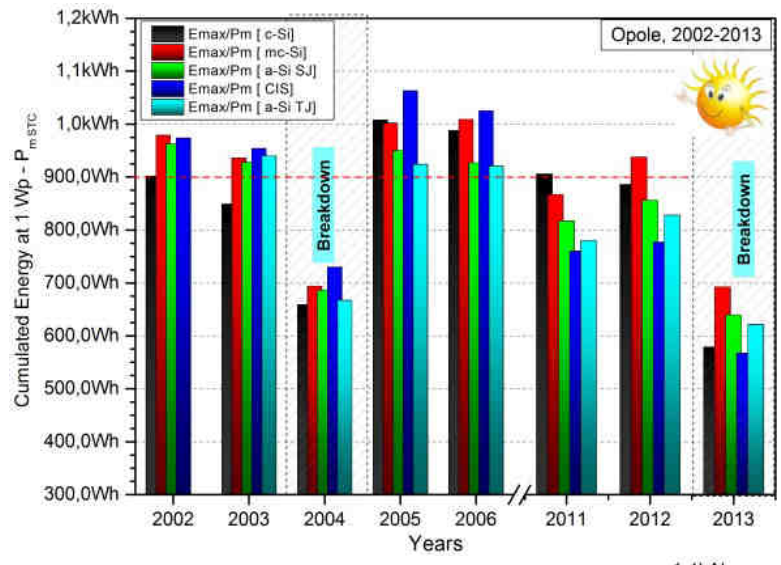

b)

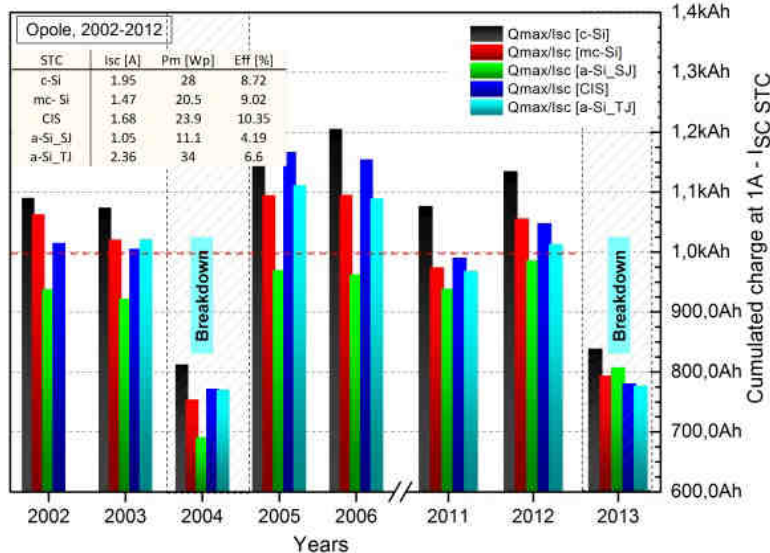

Fig. 8. Yearly yields: a) the energy in relation to $1 \mathrm{~W}_{\mathrm{p}}$ of $P_{m}$ of installed modules in STC conditions, b) the charge in relation to $1 \mathrm{~A}$ of $I_{S C}$ of installed modules in STC conditions. The study was conducted in the years 2011-2013

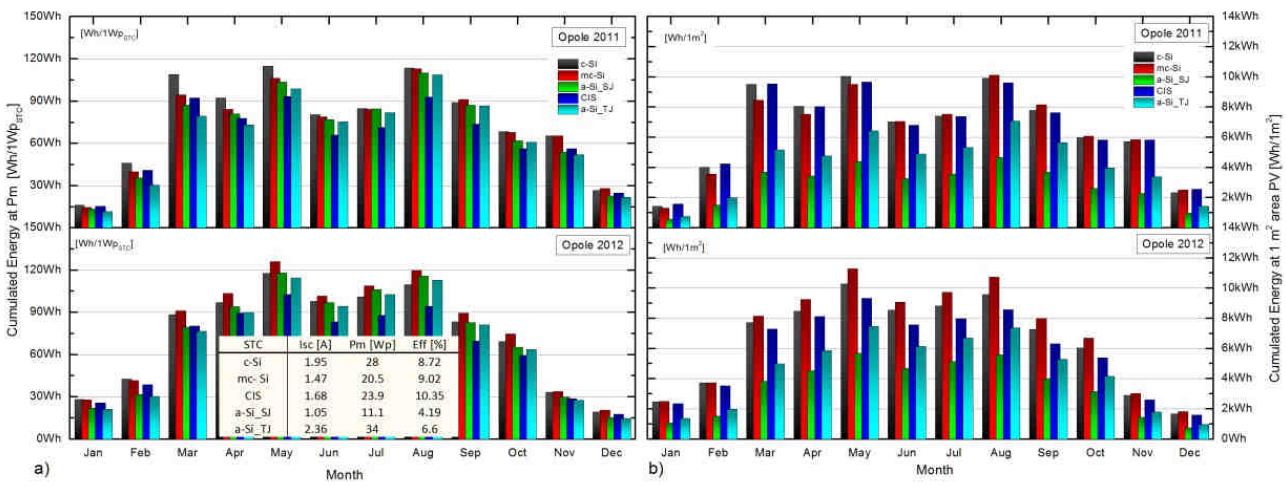

Fig. 9. Monthly yields: a) the energy in relation to $1 \mathrm{~W}_{\mathrm{p}}$ of $P_{m}$ of installed modules in STC conditions, b) the energy in relation to the $1 \mathrm{~m}^{2}$ active surface of the tested PV modules. The study was conducted in the years 2011-2012 


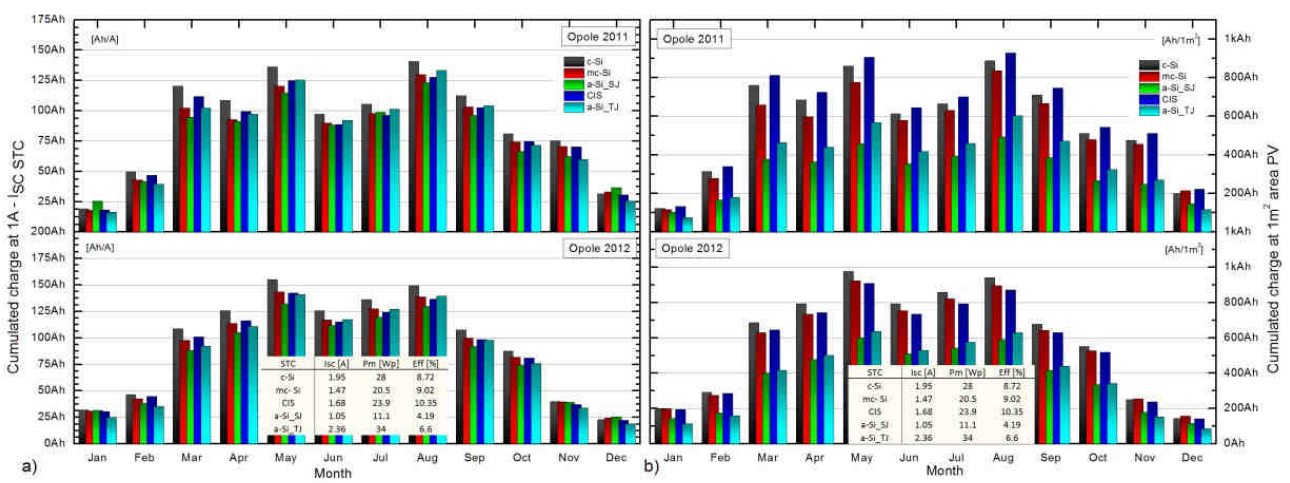

Fig. 10. Monthly yields: a) the charge in relation to $1 \mathrm{~A}$ of $I_{S C}$ of installed modules in STC conditions, b) the charge in relation to the $1 \mathrm{~m}^{2}$ active surface of the tested PV modules. The study was conducted in the years 2011-2012

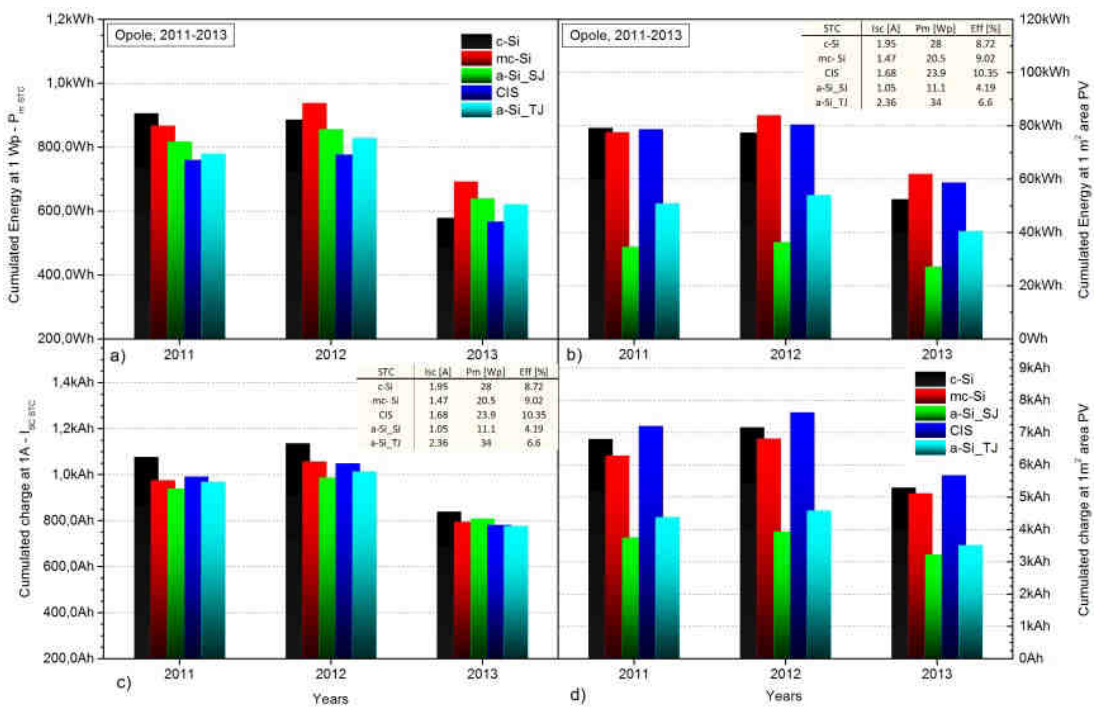

Fig. 11. Yearly yields: energy (a) / charge (b) in relation to $1 \mathrm{~W}_{\mathrm{p}}$ of $P_{m}$ and $1 \mathrm{~A}$ of $I_{S C}$ respectively, of installed modules in STC conditions, energy (c) / charge (d) in relation to the $1 \mathrm{~m}^{2}$ active surface of the tested PV modules. The study was conducted in the years 2011-2013

In Figures $8 \mathrm{a}$ and $\mathrm{b}$ energy and charge yield at such a designated reference parameter values under STC are summarized. The analysis of the annual energy yield in relation to $1 \mathrm{~W}_{\mathrm{p}}$ power of the tested modules shows that the highest potential for energy accumulation had mc-Si and CIS modules, obtaining respectively in years: 2002 - 979 and $974 \mathrm{Wh}, 2003$ - 936 and $954 \mathrm{Wh}, 2004$ - 694 and $730 \mathrm{Wh}, 2005$ - 1002 and $1036 \mathrm{Wh}, 2006$ - 1009 and $1025 \mathrm{Wh}$ per $1 \mathrm{~W}_{\mathrm{p}}$ installed power. Other modules obtain from 4 to $10 \%$ (in 2005) energy less than the module with optimum performance. Figures 9-11 present received monthly energy and charge yields over the 2011 and 2012 in relation to $1 \mathrm{~W}_{\mathrm{p}}$ power and $1 \mathrm{~m}^{2}$ of tested PV modules. They present practical information for installers of PV systems on the 
possible monthly and annual energy and charge yield originating from PV station power of " $x$ " $\mathrm{W}_{\mathrm{p}}$ PV modules or covered surface of boxes/roof " $S$ " $\left[\mathrm{m}^{2}\right]$, oriented south and tilted at an angle of about $38^{\circ}$.

\section{Seasonal changes in PV module properties}

In purpose to demonstrate the phenomenon of occurring seasonal changes in the properties of PV modules, was conducted a long-term (2011-2012) analysis of the distribution - normalized energy efficiency and $P R$ coefficient of tested PV modules.

Figure 12 shows a comparison of monthly values normalized energy efficiency, calculated from equations (1)-(3) with the values of the $P R$ coefficient calculated from (4). Distributions of these values show the strong seasonal changes in the properties of the individual modules and their suitability to work in these conditions. Very clearly show up decreases and increases energy efficiency and $P R$ coefficient of individual PV modules at selected times of the year in relation to the other.

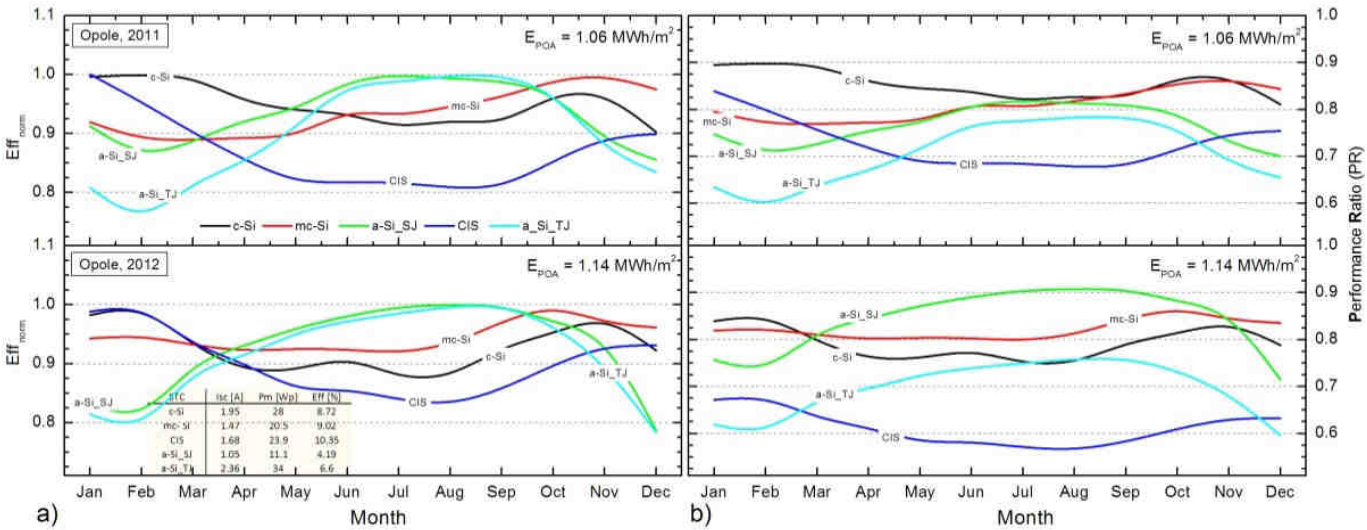

Fig. 12. Comparison of monthly values: a) normalized energy efficiency Eff $_{\text {norm }}$, b) average monthly $P R$ values for different PV modules. The study was conducted in the years 2011-2012 in Opole

\section{Aging changes in PV module properties}

The test stand with photovoltaic modules has been running at the University of Opole from September 1998 (at the beginning with two $30 \mathrm{~W}_{\mathrm{p}}$ modules made of monocrystalline silicon (c-Si)). By 2001, held the calibration and trial run. Full complete set in other modules have been made in the following time periods:

$$
\begin{array}{lll}
\text { - modules: } & \text { mc-Si, CIS, a-Si_SJ } & \text { - July } 2001 \\
\text { - module } & \text { a-Si_TJ } & \text { - August } 2002
\end{array}
$$

In this study, July 2001 was assumed as the beginning of the modules testing process except the module with a-Si_TJ (August 2002). The tested PV modules were installed on inclined at an angle of $38^{\circ}$ (and directed to the south) platform set over the rooftops of Opole University building at kard. B. Kominka Street. Their work took place in very unfavourable thermal conditions, especially in the hot summer months. Occurring very large solar radiation at the prevailing high ambient temperatures at the same time, supported 
a strong infrared radiation coming from the roof covering (black asphalt paper) resulted in a very rapid aging of the tested modules (degradation of its structure).

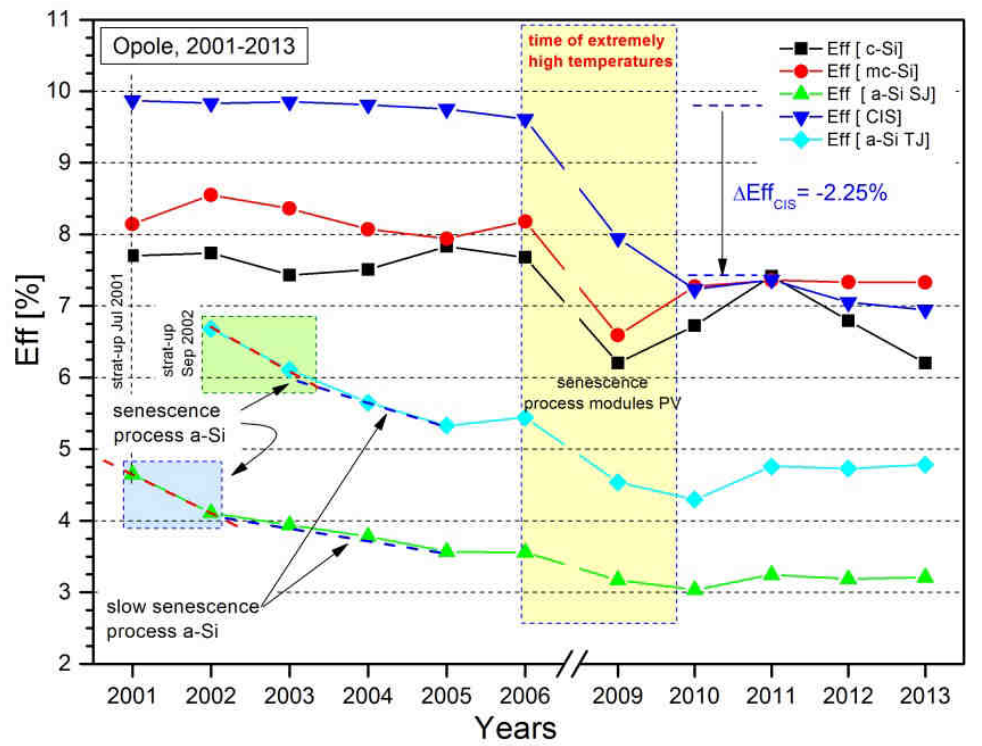

Fig. 13. Aging processes occurring in the tested PV modules in years 2001-2013

Modules made of amorphous silicon single and triple junction passed very fast initial process of aging, which resulted in a decrease in the first 12 weeks of their work overcapacity and energy efficiency to the catalogue values (see Figure 12). In a further period of time after the initial period of aging of these modules were concluded slow aging process of amorphous silicon. As a result, further decrease in their annual energy efficiency, ie from 6 to $5.5 \%$ for a-Si_TJ and 4.19 to $3.6 \%$ for c-Si_SJ obtained in 2006 (see Figure 12).

In the remaining modules, ie mono- (c-Si), multicrystalline (mc-Si) silicon and CIS modules, in this period, the material aging effects have not been found. The prevailing extreme working conditions, very cold winters and hot summers (see Figure 5 appear very large spreads of the daily efficiency values comparing to their average annual value caused by extreme cold and hot conditions) caused permanent damage in 2003, one of the two tested $12 \mathrm{~W}_{\mathrm{p}}$ modules made of amorphous silicon ( $\mathrm{a}-\mathrm{Si} \mathrm{S} \mathrm{SJ}$ ). This module has been disconnected from the measuring system. The second very strong thermal extreme, which took place in summer 2007, resulted in visible effects of aging for a module made of CIS. This module has reduced its annual energy efficiency by about $2.25 \%$, ie there was a decrease of its original value of 9.6 to $7.35 \%$. Reduced efficiency, this module further maintained, ie since 2009 in a stable manner, without showing the occurrence of further effects of aging.

In Tables 1 and 2 the averaged values of energy and charge yield of the tested modules in relation to $1 \mathrm{~W}_{\mathrm{p}}$ their capacity in terms of STC and $1 \mathrm{~m}^{2}$ are shown. Averages were made for the first 6-year period of their work, ie the strong effect of aging on the CIS module, and 
the last two years of their work from the period after the above-mentioned effect. In addition, the included ratio $\delta\left[E_{\max }\right]$, which shows the degree of deterioration of the energy and charge accumulation ability for individual PV modules after enduring in 2007 a strong thermal aging (thermal degradation).

Average values of energy yield ${ }^{4}$

\begin{tabular}{|c|c|c|c|c|c|}
\hline \multirow{2}{*}{$\begin{array}{c}\text { Mean yields } \\
\text { for the } \\
\text { period }\end{array}$} & \multicolumn{2}{|c|}{ 2002-2007 } & \multicolumn{2}{|c|}{ 2011-2012 } & $\delta\left[E_{\max }\right]$ \\
\hline & $\begin{array}{c}E_{\max } / 1 \mathbf{W}_{\mathrm{p}} P_{m} \\
{\left[\mathrm{kWh} / \mathrm{W}_{\mathrm{p}}\right]}\end{array}$ & $\begin{array}{c}E_{\max } / 1 \mathrm{~m}^{2} S_{P V} \\
{\left[\mathrm{kWh} / \mathrm{m}^{2}\right]}\end{array}$ & $\begin{array}{c}E_{\max } / 1 \mathrm{~W}_{\mathrm{p}} P_{m} \\
{\left[\mathrm{kWh} / \mathrm{W}_{\mathrm{p}}\right]}\end{array}$ & $\begin{array}{c}E_{\max } / 1 \mathbf{m}^{2} S_{P V} \\
{\left[\mathrm{kWh} / \mathrm{m}^{2}\right]}\end{array}$ & {$[\%]$} \\
\hline $\mathrm{c}-\mathrm{Si}$ & 0.903 & 81.849 & 0.864 & 78.336 & -4.29 \\
\hline $\mathrm{mc}-\mathrm{Si}$ & 0.981 & 87.818 & 0.903 & 80.774 & -8.02 \\
\hline a-Si_SJ & 0.942 & 39.949 & 0.837 & 35.477 & -11.20 \\
\hline CIS & 1.004 & 103.877 & 0.769 & 79.541 & -23.43 \\
\hline a-Si_TJ & 0.928 & 60.474 & 0.805 & 52.403 & -13.35 \\
\hline
\end{tabular}

Average values of charge yield

Table 2

\begin{tabular}{|c|c|c|c|c|c|}
\hline \multirow{2}{*}{$\begin{array}{c}\text { Mean yields } \\
\text { for the } \\
\text { period }\end{array}$} & \multicolumn{2}{|c|}{ 2002-2007 } & \multicolumn{2}{|c|}{ 2011-2012 } & $\delta\left[E_{\max }\right]$ \\
\hline & $\begin{array}{c}Q_{\max } / \mathbf{1 A} I_{S C} \\
{[\mathrm{kAh} / \mathbf{1 A}]}\end{array}$ & $\begin{array}{c}Q_{\max } / 1 \mathrm{~m}^{2} S_{P V} \\
{\left[\mathrm{kAh} / \mathrm{m}^{2}\right]}\end{array}$ & $\begin{array}{c}Q_{\max } / \mathbf{1 A} I_{S C} \\
{[\mathrm{kAh} / \mathbf{1 A}]}\end{array}$ & $\begin{array}{c}Q_{\max } / 1 \mathrm{~m}^{2} S_{P V} \\
{\left[\mathrm{kAh} / \mathrm{m}^{2}\right]}\end{array}$ & {$[\%]$} \\
\hline $\mathrm{c}-\mathrm{Si}$ & 1.145 & 7.226 & 1106 & 6.980 & -3.40 \\
\hline $\mathrm{mc}-\mathrm{Si}$ & 1.069 & 6.890 & 1015 & 6.545 & -5.00 \\
\hline a-Si_SJ & 0.948 & 3.786 & 962 & 3.842 & 1.50 \\
\hline CIS & 1.086 & 7.895 & 1019 & 7.414 & -6.09 \\
\hline a-Si_TJ & 1.074 & 4.856 & 991 & 4.479 & -7.76 \\
\hline
\end{tabular}

The analysis which was set in Tables 1 and 2 shows that after the strong thermal extreme in 2007 modules have not lost their ability of energy and charge accumulation. The observed decreases in their ability at the level of few percent, are located in the errors tolerance resulting from large differences in test years. On the other hand, the observed decreases the ability of energy accumulation, which reaches for CIS module to $23.4 \%$ (equivalent to reducing its nominal efficiency of $2.25 \%$, and $5.59 \mathrm{~W}_{\mathrm{p}}$ its nominal power) indicates a significant deterioration in the FF factor of the module. This deterioration of FF factor is the consequence of the series resistance increase in the module which is evident when working in sunny days, and an increase in leakage current (ie a decrease in the parallel resistance - so-called leakage resistance) as a result of thermal degradation of the PV module structure (PV module absorber and internal junctions).

An analysis of available catalogue data of commercial PV modules, we can draw the thesis that the processes concerning encapsulation (closing/sealing) cells in PV modules have already been worked out for all types of modules. Therefore, the current standard is to give their 10-year warranty on mechanical damage (not thermal) for different PV modules. The above thesis is confirmed by 13 years of tests conducted at the Opole University, during which there was no mechanical damage to any of the tested modules.

\footnotetext{
${ }^{4}$ All yields shown in respect of the actual power and current have reached tested modules (c-Si, mc-Si and CIS) under the STC at the beginning of operation. The values declared by manufacturers weren't taken into account. In the case of modules made of a-Si single- and triple-junction, were taken the parameters obtained during their annual work obtained also in STC.
} 
Quite differently, the issue of long-term preserving of their parameters. The results of the study which are presented in Tables 1 and 2 and in Figure 13, confirm the validity of the provision of 10/25 years guarantee given by leading manufacturers of modules with cells mono- (c-Si) and multi-crystalline (mc-Si) for preserving, during operation, their power/efficiency at the level of, respectively, 90/80\% of the nominal value. In the case of modules made of amorphous silicon ( $\mathrm{a}-\mathrm{Si}$ ) single and triple junction strong aging effect especially in the first period of its work (see Table 1) results in the necessity of increase of their initial value of power/efficiency, so that at least after the initial period of aging power was within the limits of its nominal power. For this type of modules is today still a risky provision of guarantees to maintain 80 to $90 \%$ of the nominal value of their power/efficiency for more than 10 years in the natural conditions, even with the initial power redundancy. In the case of the module made of CIS, was found a very high stability of the parameters both in the first 6 years of operation ie to summer 2007, when performed, the effect of thermal degradation, reducing the efficiency/nominal power, as well as its operation in the following after the above-mentioned phenomenon.

Due to the fact that only one module made of CIS was tested (for statistical reasons in the study sample was unrepresentative) it is difficult to specify general conclusions and reasons. The fact is, however, that: 1) the module decreased its performance under extremely difficult to operate conditions, 2) as in the case of amorphous silicon, $20 \mathrm{~W}_{\mathrm{p}} \mathrm{CIS}$ module have nearly $4 \mathrm{~W}$ of power (added by the manufacturer) exceeding its nominal power, 3) the manufacturer gave an only 10-year warranty for mechanical damage of module. To clarify the reasons above-mentioned phenomenon, it should be made additional long-term studies on statistically representative samples with many types of different modules.

Considering the fact of adding at the production stage of CIS module $\sim 4$ watts nominal compared to the value declared by the manufacturer (ie $\sim 20 \%$ to $20 \mathrm{~W}_{\mathrm{p}}$ module), the $23.4 \%$ decrease in the energy accumulation ability, which occurred in 13 years of its operation, as a result of aging reduce of the power (20 to $18.41 \mathrm{~W}_{\mathrm{p}}$ ) - does not result in a reduction in its capacity below $90 \%$ of the declared value.

\section{Investment profitability analysis for the PV in a climate of Southern Poland}

To analyse the profitability of investments, was taken $25 \mathrm{~kW}_{\mathrm{p}}$ photovoltaic system connected to the grid, with modules oriented towards the south with a constant $38^{\circ}$ inclination to the plane of the horizon. The system is built from commercially available multicrystalline PV modules and a $20 \mathrm{~kW} 3$-phase inverter. The annual energy yield for mc-Si is not less than $942 \mathrm{kWh}$ for installed $1 \mathrm{~kW}_{\mathrm{p}}$ (see Table 1 - the mean value for two periods for mc-Si). Furthermore, assume the possibility of putting the whole of the electricity to the grid and accountability of Energy Company (ZE) in one of two options:

a) the preferred price ie $1.10 \operatorname{PLN}(0.264 €)$ - which will take place after the entry into force of the Law on RES and implementation FIT type (Feed-in Tariff) support for renewable energy,

b) the price of the sale by Energy Company (ZE), ie 0.56 PLN (0.134 €) - in the case of no ability to sell green energy at a preferential price, but the existence of the possibility 
of accounting for the $\mathrm{ZE}$ in the form of the annual balance sheet for supplied and consumed power from network.

\section{Investment Costs:}

- Polycrystalline PV module $245 W_{p}+$ transportation $500 €$ type: Atakama (Siliken) ATK-P60U 235/240/245 Poly [14]:

$$
0.58 € \times 245 \times 102+500=14994.2 €
$$

- Photovoltaic inverters: 3-phase $20 \mathrm{~kW}$ :

type: Power-One Aurora TRIO 20.0-TL-OUTD (S2/S2F/S2X) [14]:

$$
3171.7 € \times 1 \quad=3172 €
$$

- Transportation: $\quad 500 € \times 1=500 €$

\section{Together}

netto: $18666.2 €$

brutto: $22959.4 €$

brutto $(1 €=4.17$ PLN $)=95740.8$ PLN

\section{Interest rate $25 k W_{p} \underline{P V \text { system: }}$}

a) for price $1 \mathrm{Wh}=1.10 \mathrm{PLN}-$ (after the entry of the Act on RES)

Installation costs:

95 740.8 PLN - without labour costs

Yearly profit from $25 \mathrm{~kW}_{\mathrm{p}} \mathrm{PV}$ system:

25 x $942 \mathrm{kWh} /$ year $\times 1.1 \mathrm{PLN} / \mathrm{kWh}=25905 \mathrm{PLN}$

Stable tariff for 15 years 15 x 25905 PLN = 388575 PLN

Profit: $388575-95740.8=292834.2$ PLN

Guaranteed annual level of return on investment:

$$
100 \% \text { x (292 834.2/95 740.8) / } 15 \text { years }=\underline{\mathbf{2 0 . 3 9 \%}}
$$

b) for price $1 \mathrm{kWh}=0.56 \mathrm{PLN}$

Installation costs: 95 740.8 PLN - without labour costs

Yearly profit from $25 \mathrm{~kW}_{\mathrm{p}} \mathrm{PV}$ system:

$$
25 \text { x } 942 \mathrm{kWh} / \text { year x } 0.56 \mathrm{PLN} / \mathrm{kWh}=13188 \mathrm{PLN}
$$

Stable tariff for 15 years $15 \times 13188$ PLN = 197820 PLN

Profit: 197820 PLN - $95740.8=102$ 079.2 PLN

Guaranteed annual level of return on investment:

$$
100 \% \times(102079.2 / 95740.8) / 15 \text { years }=\underline{\mathbf{7 . 1 0 \%}}
$$

Recognizing that we have purchased multicrystalline PV modules with a guaranteed for them 25-30 years of preserving its energy efficiency/power we have 10-15 years of able-bodied PV system producing electrical energy.

\section{Conclusions}

As a result of investigation (in 2002-2013) of modules made of different materials and in different technologies strong seasonal changes of energy and charge gained were observed. The following conclusions could be drown $[1,12,13]$ : 
1. Significant improvement of parameters of modules made of a-Si in summer and autumn months characterized by warm days with high humidity and in cloudy days.

2. Aggravation of parameters of modules made of a-Si in winter months characterized by cold days with low humidity and high value of air mass factor AMx (strong damping of short wavelength component of solar spectrum).

3. Modules made of c-Si have the best parameters in sunny winter days, in season of higher values of air mass factor and small component of water vapour. In warm months their capability of accumulation of energy is near $20 \%$ lower than in modules made of a-Si SJ and TJ.

4. Modules made of mc-Si have the best parameters in spring and summer months (with high value of insolation). During hot summer days they gain $\mathrm{ca} 8 \%$ energy more than modules made of amorphous silicon.

5. Modules made of CIS have the best parameters in spring-winter period (low ambient temperatures and high value of the air mass factor). They have the worst parameters in warm and cloudy days. Then their capability to accumulate energy is lower by $8 \%$ in comparison with modules made of amorphous silicon.

6. Modules made of $\mathrm{c}-\mathrm{Si}$ and $\mathrm{mc}-\mathrm{Si}$, are still more resistant to work under severe climatic conditions, and the taking place aging processes are significantly lower compared to the thin film modules (ie made of a-Si or CIS - see Fig. 13). Therefore, the leading manufacturers of these modules ensure that during the 10/25-year of their work, conversion efficiency / power does not drop below respectively $90 / 80 \%$ of its nominal value. In the case of other modules, in particular made of a-Si does not provide this guarantee, yet.

7. From analysis of yearly energy gain per $1 \mathrm{~W}_{\mathrm{p}}$ power of tested modules stems, that the largest capability to accumulate energy has module made of mc-Si and CIS. Other modules have parameters worse than optimal one.

In conclusion, it must be said that in terms of Southern Poland development of photovoltaic investment is ecological (reducing emissions of harmful gases and dust), and economically justified. Implementation of a program of support for renewable energy by guaranteeing 15-year fixed tariff acceptance of green energy, much shorter payback period of PV. Doing that, the annual rate of return on investment of a typical $25 \mathrm{~kW}_{\mathrm{p}}$ PV system built with durable and reliable cell multicrystalline (mc-Si) exceeds $20 \%$ at minimal cost and effort incurred own works during his long life. Furthermore, it should be noted that even after 15 years of operation, the system will still be able to work for the next 10-15 years generating further energy of the same year value.

\section{References}

[1] Wacławek M, Rodziewicz T. Ogniwa słoneczne. Wpływ środowiska naturalnego na ich pracę. Warszawa: WNT; 2011.

[2] Planning and Installing Photovoltaic System: A guide for installers, architects and engineers. Editors. James\&James/Earthscan (Science Publishers) Ltd in UK and USA; 2005; 49-75.

[3] IEC 61724: Photovoltaic System Performance Monitoring - Guidelines for Measurement, Data Exchange and Analysis.

[4] Blaesser G, Munro D. Guidelines for the Assessment of Photovoltaic Plants. Analysis and Presentation of Monitoring Data. ECSC-EC-EAEC. Luxemburg: 1993.

[5] IEC-60904-3: Photovoltaic devices. Part 3: Measurement principles for terrestrial photovoltaic (PV) solar devices with reference spectral irradiance data. Geneva: 1989. 
[6] IEC-60891: Procedures for temperature and irradiance corrections to measure I-V characteristics of crystalline silicon photovoltaic devices. Geneva: 1987.

[7] Coors S, Böhm M. Validation and comparison of curve correction procedures for silicon solar cells. Proc 14th EC PVSEC. Barcelona: 1997; 220-223.

[8] Coors S, Böhm M. Application of the two-exponential model to correction procedure for silicon solar cells. 1st EuroSun (1996). 614-619.

[9] Luque A, Hegedus S, editors. Handbook of Photovoltaic Science and Engineering. Chichester, England: John Wiley \& Sons; 2003.

[10] Anderson AJ. An energy rating concept for photovoltaic modules. Final Report for Task 2.0. NREL subcontract No. TAD-4-14166-01 (1995).

[11] IEC 61853 (draft 82/254): Performance testing and energy rating of terrestrial photovoltaic (PV) modules.

[12] Żdanowicz T, Rodziewicz T, Wacławek M. Evaluation of actual PV Modules Performance in Low Insolation Conditions. Opto-Electronics Review. 2001;9(4):361-366.

[13] Rodziewicz T, Teneta J, Zaremba A, Wacławek M. Analysis of solar energy resources in Southern Poland for photovoltaic applications. Ecol Chem Eng S. 2013;20(1):177-198.

[14] Internet shop: http://pvshop.eu/.

\section{ASPEKTY TECHNICZNE I EKONOMICZNE KONWERSJI FOTOWOLTAICZNEJ W WARUNKACH POLSKI POŁUDNIOWEJ}

${ }^{1}$ Zakład Badań Fizykochemicznych, Wydział Przyrodniczo-Techniczny, Uniwersytet Opolski

${ }^{2}$ Instytut Elektrotechniki Przemysłowej, Wydział Elektryczny, Politechnika Częstochowska

Abstrakt: W artykule przedstawiono wyniki 13-letniej analizy testowania sprawności oraz uzysku energii i ładunku elektrycznego typowych modułów fotowoltaicznych wykonanych $\mathrm{z}$ różnych absorberów, zainstalowanych na południowej ścianie budynku Uniwersytetu Opolskiego przy ulicy kard. B. Kominka. Zarejestrowane w tym okresie (2001-2013) wartości kumulacji energii i ładunku testowanych modułów przedstawiono zarówno w odniesieniu do $1 \mathrm{~W}_{\mathrm{p}}$ ich mocy nominalnej, jak i do $1 \mathrm{~m}^{2}$ powierzchni modułów PV. Przedstawiono ich roczne i miesięczne rozkłady ze szczególnym uwzględnieniem sezonowości zmian ich parametrów oraz zjawiska starzenia i degradacji struktury modułów PV. W końcowej części artykułu zaprezentowano ekonomiczną analizę opłacalności $20 \mathrm{~kW}_{\mathrm{p}}$ inwestycji PV typu Grid Connected bez i z wdrożonym programem wsparcia inwestycji w OZE, tj. uwzględniające zapisy nowo wdrażanej w Polsce Ustawy o OZE.

Słowa kluczowe: solar cells, energy gained, energetic efficiency, performance ratio (PR), solar radiation, solar energy, photovoltaics 